\title{
Africa and Its People in the Polish Media
}

\author{
PAWEŁ ŚREDZIŃSKI \\ 'Africa Another Way' Foundation \\ Fundacja Afryka Inaczej \\ ul. Sarmacka 15/6 \\ 02-972 Warszawa, Poland \\ www.afryka.org \\ fundacja@afryka.org
}

\begin{abstract}
The African continent is treated by the Polish media marginally and usually seen through the lens of four domains of stereotypical perceptions that are associated with difficult life conditions, threats and dangers, beautiful and wild nature, as well as original and diverse cultures. Monitoring of the Polish media has become very important in this situation. That is why the results of first media monitoring report were published in 2011 by 'Africa Another Way' Foundation. Five years later the monitoring was repeated. It is hard to resist the impression that Africa is still viewed as this poor, underdeveloped and dangerous continent. And the way it is presented translates into the way individuals of African descent are perceived.
\end{abstract}

Keywords: Africa; Poland; Polish media; stereotypes; Africans in Poland; African diaspora

\section{Introduction}

Africa and its inhabitants do not constitute a major presence in Polish media reports. Media consumers in our country receive sparse information about Africa and based on those cursory contacts they do create a certain image of African and Africans. This translates into Polish people's knowledge. The African continent is treated marginally and usually seen through the lens of four domains of stereotypical perceptions that are associated with difficult life conditions, threats 
and dangers, beautiful and wild nature, as well as original and diverse cultures. These are the domains indicated by respondents who participated in the public opinion poll conducted in 2015, which was commissioned by the 'Africa Another Way' Foundation (Duński 2015: 24).

The studies show that media (press, radio, and television) are the most important and, in most cases, the only source of information about Africa: $77 \%$ of all respondents listed these media as their basic sources of knowledge. The remaining 23\% indicated online publications. Only $8 \%$ of all Poles stated that they frequently encountered information about Africa in media. Half of the respondents admitted to having sporadic contact with positive information about the African continent, whereas $44 \%$ received sporadic negative information. Less than a half of all Poles learned from the media about good examples of African people's integration in Poland. $1 / 3$ of all respondents claim that they encountered insulting descriptors of individuals of African descent online. Equally as many individuals admitted to coming across racist statements by public persons. At the same time, Poles are not looking for knowledge about Africa. It reaches them via media and mostly on occasion of extreme occurrences, such as all sorts of calamities, conflicts, and crises. According to the respondents, the media present mainly the information that refers to difficult living conditions (hunger, diseases, AIDS, Ebola), wars (internal conflicts, Somalian pirates), terrorism, and humanitarian aid (fund-raisers, and charity actions) (Duński 2015: 27-29).

The following are statements made by some of the respondents: "The press and media in general very often have special shows [such as]: Whatever for Africa, Footballers or singers for Africa. For poor children. Recently, a famous footballer had a tattoo done to raise funds for some children." Concurrently, respondents indicated that should one come across any positive information about Africa, then it is via travel shows, but those most often focus on describing the harsh living conditions Africans in rural areas have to live in, or they are about wilderness (Duński 2015: 29).

Other data show the scale of the influence of media on the way Africa and its inhabitants are perceived in Poland - only $4 \%$ of the questioned Poles gain their knowledge from friends who have been to Africa. $3 \%$ of the Polish people recall personally meeting and talking to Africans. $2 \%$ have their own observations from their visits to Africa (Duński 2015: 27).

\section{Methodology}

Monitoring of the Polish media has become very important in this situation. Six years ago, that is in year 2011, we published the first media monitoring report. 
We had been scrutinising practically all media bits about Africa and its inhabitants for 12 months, as part of a daily review offered by the Institute of Media Monitoring [Instytut Monitorowania Mediów, IMM] (Średziński 2011). We repeated this monitoring between March 1, 2015 and February 29, 2016. This time, we expanded our research significantly by incorporating bits from electronic media that have recently experienced a dynamic growth and our data have not been limited only to page numbers or show length.

These past 12 months when the latest monitoring took place were a completely different reality than the time five years back when the previous study was performed. The refugee crisis in Europe focused public opinion's attention on this particular issue, shared by the whole European Union. While the media was repeatedly returning to the recent Ebola epidemic in a number of West-African countries, in Poland we witnessed Polish celebrities of African descent coming out with a courageous message about their own experiences of functioning in the Polish reality.

The keywords for the monitoring included Africa, African, and Murzyn [Negro]. Murzyn is a descriptor that individuals of African origin who live in Poland consider to be derogatory and lacking any positive meaning. Special attention was devoted to the image of Africa and its inhabitants by means of conscious creation of negative or positive imagery. Among reports of this type we found those that described known individuals of African origin who live and enjoy media careers in Poland. Aside from this, the monitoring also included statements of known Poles, including politicians, about Africa and Africans. Furthermore, unexpectedly the refugees issue appeared, in relation to the dramatic development of the migrant crisis.

The monitoring by IMM included over 1,200 media outlets from the group of press, radio, and television, as well as over 10,000 online media sources and posts on social media. In this way, we were guaranteed access to a wide array of types of clippings and bits, with the report mainly focusing on press, radio, and television, which the Polish people declare as their main sources of information. A special emphasis was placed on the widest-reach media considered to be opinion-making and frequently quoted outlets.

The clippings and bits were available via a special website which served for selection and further content analyses. Concurrently, we prepared a summary of each month with reference to the words Africa and Murzyn, including frequency of their use, source, and author.

The present report is a result of the monitoring. Its purpose was to capture the possible changes in the perception of Africa and Africans in comparison with an analogous report from five years ago. This time, the report is also enriched by information from the media of three Polish towns that were previously 
included in public opinion polls. Additionally, due to the appearance of the issue of refugees, the present report includes not only the portrayal of Africans in Polish media, but also of other cultures and migrants who have become subjects of not just political, but also general media debates.

\section{Ebola, Negroes and political correctness}

In the media, Africa is still associated with poverty, hunger, and famine. People of African origin are still called Murzyn [Negro]. However, we can also see a certain regularity in that the word is predominantly used in the right-wing media as a weapon in the fight against political correctness.

The Ebola epidemic effect helped perpetuate the conviction about the entire continent of Africa being plagued. Even though the Ebola outbreak affected only a small number of West African countries, by generalization it was ascribed to the entire continent. It still stimulates imagination and is a subject that excellently sells in media, in accordance with the rule that the bloodier and more horrible the event the better it will sell to public opinion. W piekle eboli [In the Hell of Ebola] - a book by Tomasz Biedzki - became a sort of reminder of this epidemic; it was published after it ended, but it made its way to the Polish media ("W piekle eboli" 2016).

Biedzki has been travelling to Africa for over 25 years now. He claims that there is no other continent like this one, because it is the most uncommon and colourful. Attempting to write his latest book, the author revealed: "This time I wanted to see Africa struggling with Ebola and understand how people there react to disasters" (Jankowska 2015). He was afraid to take this trip, but "adrenaline and satisfaction were also greater" - this is how he justified his fear. And because no Polish reporter was sent to the region during the epidemic, Biedzki decided that he had to go and write a book about it. He was not aware of the fact that his would become the first book ever written about Ebola in Africa. Biedzki emphasized that Africans cannot get a grip on Ebola: "They do not believe in the existence of the virus. They think that it is a curse, a kind of possession, or that spirits caused the disease" (Ibidem) - he reported.

Biedzki's journey is terrifying because it takes us to the blight country; and it is the blight that according to Marek Magierowski, the current spokesperson for President Andrzej Duda, floats around the coast of Malta. Magierowski writes about the "plague year" quoting a post by one citizen of Malta who "removed fish from his diet - we cannot eat them, since corpses infected with Ebola float around the shoals" (Magierowski 2015).

The world of diseases and epidemics generates extensive media coverage. Consequently, Ebola ideally inscribes itself in a narration that is supposed to 
terrify and frighten with disease descriptions, especially when there are victims and those who came out victorious from the battle with the virus. Dr. Ian Crozier - a doctor who survived thanks to being transported to an American hospital can be a good example. Other reports about Ebola were also published. In 2015, Duży Format, an insert in the Polish daily titled Gazeta Wyborcza, published a photo report devoted to how Sierra Leone makes use of airwaves to prevent spreading of Ebola. Radio is the main information channel in this country, hence the idea of radio shows whose aim was to remind the citizens about security measures to be undertaken in order to avoid a virus infection ("Radio Ebola" 2015).

African diseases stimulate the imagination of readers, listeners, and viewers. At the same time, they inscribe themselves in the stereotype of the African continent as a place where serious diseases originate and where representatives of "other civilization" dwell. The Polish word Murzyn [Negro] describes individuals who come from this "culturally distinct" land, and it emphasizes their being disadvantaged. Whereas Africans who have been living in Poland for a long time and who know the Polish language well feel the contemptuous meaning of the term Murzyn [Negro], media still occasionally crusade against replacing the word Murzyn with Afrykanin [African]. As a result, people who declare malevolent disapproval of individuals of African origin Murzyn personifies political correctness.

During the examined period, media, including online and social ones, clearly more frequently used the word Murzyn instead of Afrykanin. To use numbers, this meant 153,781 clippings and bits where Murzyn appeared and 14,396 with Afrykanin. This lets us conclude that Polish media, especially social media, still more frequently use the word Murzyn to describe a black-skinned individual.

On television, the word Murzyn appeared frequently in statements by Mariusz Max Kolonko. Superstacja proved to be most active in commenting on this issue. It is from Kolonko that we learned that one can have "murzyńskie usta" [negro lips] or follow "murzyńskie obyczaje" [negro customs]. However, Kolonko never clearly explained what the latter of the two was supposed to mean. Still, he did not shrink from commenting on the famous U.S. case of Rachel Dolezal who pretended to be African-American despite of being white. Kolonko did not hide his astonishment with a white woman pretending to be black. Kolonko described the Dolezal case in a way that is characteristic for him: indeed, he is aware of cases when black people wanted to be white and when much more frequently and eagerly than "our very own Murzynek Bambo" ${ }^{1}$ they wanted to whiten the pigment of their complexion. So how would a white woman want to become black? Kolonko had a ready response to this dilemma: this woman has contracted the bacteria of political correctness. He went on to explain the motives

1 "Bambo, the Negro Boy" - a character from a nursery rhyme, popular in 1960s and 1970s in Poland. 
of her behaviour by analysing her family's history: Dolezal's parents were missionaries in Africa, they adopted a black child, and were open to "multi-culti" 2 and race-mixing. Growing up in such an environment, Dolezal herself became fascinated with it. Moreover, being artistically talented, she painted pictures of these "Negroes." According to Kolonko, thanks to her works she received a scholarship from Harvard University where she sent her works to. Representatives of this university must have concluded that she herself must have been black. Kolonko's narration is full of common language and colloquialisms: "Their jaws dropped when they realized she was white. She sued them for this, but she lost. Then she had some hardships and even failed at dating a black guy." Hence, Kolonko offered his own thesis: Dolezal noticed that "multi-culti" does not work, but instead of shoving away the black race, she rejected her parents who implanted her with the bacteria of political correctness. She decided to recant them by pretending to be a black person. But, as Kolonko claims, we will not hear or read about this fact in American media ("Rachela Dolezal, kobieta, która oszukała USA" 2015).

Some journalists use the term Murzyn as a neutral expression that does not - and should not - fall victim of the "dictate of political correctness." In Wprost weekly, Mariusz Cieślik calls it "censorship in the name of equality" (Cieślik 2015). The article he authored includes not just his own opinions, but also those of experts. One of them is Professor Jerzy Bralczyk who dislikes replacing the term Murzyn with ciemnoskóry [dark-skinned] or even worse with Afroamerykanin [African-American], furthermore he would dislike dropping the term completely, due to its centuries-old tradition in the Polish language. On the other hand, however, he admits that this word indeed appears in various negative contexts. Concurrently, he thinks that it would be better to use it in a positive context, but he fails to show how this can be achieved. On yet another hand, Krzysztof Ibisz claims that nobody really needs political correctness. Joanna Koroniewska cannot imagine not being able to read the "excellent poem titled Murzynek Bambo" - in her opinion - to her child just because someone considers the word Murzyn as improper. After collecting these opinions, Cieślik postulates that over the course of the last 20 year, Poland has been subscribing to political correctness and its top example can be seen in language manipulation. He also laments that we will not read or hear the word Murzyn in contemporary media and sympathised with father Tadeusz Rydzyk who almost fell victim to political correctness when he jokingly publicly referred to an African clergyman as one who forgot to wash himself (Ibidem). Hence, Cieślik opposes this phenomenon and expresses his disapproval, just like most of the individuals he cites in his article.

\footnotetext{
${ }^{2}$ This is a pejorative reference to "multiculturalism."
} 
Paweł Wawrzyński is of a similar opinion. In his Do Rzeczy weekly he created a "reactionary dictionary." One of the terms there is hate speech, which this journalist defines as: "discussing negative traits of select nations and special groups. Not all of them, of course. Considering the vices of Americans, Poles, Christians, men, or economists is in good taste, yet using the same with reference to Negroes, Muslims, women, or homosexuals - becomes hate speech independently from what personal experiences confirmed [the factual occurrence of] these vices" (Wawrzyński 2016).

One can therefore get the impression that hate speech, especially in case of right-wing media, is the same kind of misconception as political correctness. It is treated as something imposed by countries that do not care about Poland. It was invented in order to make Poles' lives miserable and turn them into xenophobes. One can even get the impression that the word Murzyn is used deliberately to manifest opposition to interference in the Polish language. Nevertheless, as research conducted for the purpose of this publication shows, in some situational contexts being a Murzyn means being exploited. Such was the case in the minds of aldermen from the town of Nowa Sól. During the District Council meeting devoted to the dismissal of its female president, alderman Mirosław Olejniczak said: "It reminds me of some unpleasant and familiar behaviour which can briefly be summarised in this phrase: 'a Negro did her job, so now the Negro can go'" (Pobihuska 2015). When the Poles feel poor and humiliated they emphasise that they are like slaves, "Negroes for the buck" ${ }^{3}$ ("Listy czytelników" 2015). The word Murzyn is still not present in a positive context and is accompanied by only negative connotations.

However, one does not need to be an African to understand why the word Murzyn has changed its semantic context. In the awareness of individuals who use this term, a contemporary Murzyn is irrevocably someone inferior, a slave that is easy to subordinate, an exploited individual. Simply put, it is not enviable to be a Murzyn because this status concurrently evokes contempt.

This is why Jacek Żakowski did not want to become a Murzyn one day and he declared very clearly that smokers do not want to be "Negroes" (Źakowski 2010). And currently, from the covers of the Polityka weekly we learn that XXL-sized people, otherwise known as "the fat race," have become the "Negroes of our times" ("Rasa grubych" 2013). There is no need for further comments, because it is clear that Murzyn is not a socially desirable term nowadays. Let us then consider whether we would like to be called Murzyn before we volunteer to use this term to describe someone else. Hence, the word Murzyn has lost its geographical provenance - it no longer serves as a descriptor of someone who

\footnotetext{
${ }^{3}$ In Polish: Murzyni za grosze.
} 
comes from Africa, but began to refer to clearly pejorative contexts: it began to describe someone whom nobody wants to be.

Yet, in order not to present the Murzyn stereotype in such explicit ways it is proper to indicate spectacular and surprising changes in the meaning of the term Murzyn in the current, globalized times. In an article devoted to foreigners in Polish service centres, the Newsweek weekly shows advantages of working in multinational teams:

Working in multinational and multi-ethnic teams effectively cures one from prejudices and stereotypes. This applies to even the most inflexible individuals who failed to learn tolerance at home or consecutively at schools. Suddenly, you end up working side-by-side with someone who is routinely called a Murzyn. So at first you want to show him your Slavic hospitality and begin explaining how to use a computer and then one day during a coffee break you find out that the guy has three degrees from three different European universities, speaks four languages fluently, and his Cameroonian family is equivalent to our Radziwiłł knighted nobility. And so the Negro becomes Stanley, a friend who you used to play basketball with. (Rabij 2015)

However, independently from exceptions described above, Murzyn still appears in media clippings in this old, quite pejorative form. Fakt and Super Express tabloids use this term particularly frequently. When describing Africans, these media diversify them and indicate that there are "Negro albinos from Tanzania" ("Murzyni albinosi z Tanzanii"), but also "Negroes from other African countries" ("Murzyni z innych krajów afrykańskich"). A good example may come from the article in Fakt about the World Festival of Youth and Students that took place 60 years ago in Warsaw. The paper reports that "Negroes were especially sensational. Africans from the Congo, Nigeria, Gabon, and many other colonial countries were in seventh heaven. In their own countries they were second-category citizens treated by the Europeans with contempt, whereas in the capital of Poland they not only created quite a stir and were handing out autographs, but the beautiful white women wanted to date them as well. Some Warsaw dodgers even covered their faces and hands with black paste pretending to be Negroes" (Borkowicz 2015).

Two actors of African descent commented on the subject of Murzyn in an interview with the Wrocław edition of the Gazeta Wyborcza daily. Asked about "Murzynek Bambo" and a video clip that accompanied this poem where he played the child, Mikołaj Woubishet reminisces that initially he did not want to participate in this project, but producers convinced him that the disco-polo video clip will break through barriers and become a weapon in the fight for tolerance. As a result, performance in the clip turned against the actor and today he would not allow his sons to recite this poem at school (Piekarska 2015). 
In Poland, Murzyn is also frequently replaced with such extremely vulgar and offensive words as czarnuch [nigger], czarna matpa [black monkey], or bambus [bamboo]. This is how a Ghanaian English teacher beaten in Skarżysko-Kamienna by three young individuals was referred to. Charged with an attack on an African the assailants received prison terms without parole (Drabikowska 2015).

Similar terms were used to refer to Africans by young inhabitants of Łódź. They also beat them and were penalised for assault that the court considered racist (Pierzchala 2015). Tygodnik Siedlecki weekly reported on an inhabitant of the town of Siedlce who was charged for a racist post. As the paper informed, Rafał W. commented on an online article about immigrants in the following way: "Illegal Negroes from the African desert should be killed with knives and their bodies should be sent overseas." Rafał W. was sued for this comment and the court fined him ("Nie taki geniusz" 2015).

The term Murzyn continuously appears in the Polish media, yet until this very day no positive connotations have been ascribed to it (one cannot even be as cunning as a Murzyn anymore). Hence, defenders of this term are not right when claiming that it has positive associations in Poland and in the Polish language. At the same time, we can see that Murzyn has nowadays become one of the values that opponents of political correctness want to defend; especially comments of right-wing media reveal these tendencies particularly well.

It seems that the peculiar Polish justifications of the term Murzyn are like the following very bad joke: a man charged with racist behaviour at work comes to court. When the judge asks him whether he admits to the alleged act, the man responds: "Of course not, Your Honour! I am as racist as a black man is useful!"

\section{Refugees attack! The decline of multi-culti?}

The period this media monitoring encompassed was dominated by reports about refugees. Intensification of this theme in public space increased along with refugee arrivals in Europe. We dealt with geographical chaos especially in the initial phase of reporting on this process. Precision with regards to determining the locations most individuals seeking shelter in the European Union came from was lacking.

A good example of generalisation and direct associations of the refugee phenomenon with Africa can be found in the Piotr Semka's Do Rzeczy weekly. He wrote directly about "Afromigration" and went on to explain why this phenomenon is terrifying. In formulating his opinion, Semka referred to texts by two "left-wing columnists" who asked the following question on the pages of 
the Gazeta Wyborcza daily: "Are a Pole and a Murzyn [Negro] two nephews?" Semka recalls the two columnists' accusations against the Poles that they do not show solidarity with thousands of migrants from Africa. In a slightly apocalyptic tone, Semka stated that this migration will be endless. According to him, Europe is not ready to welcome Libyans, Malians, Chadians, because the west itself can no longer handle millions of Muslims anymore. On this occasion, Semka praises Australia and presents this country as a model for solving the refugee problem. Unfortunately, political correctness will not make it possible for the European continent to follow the Australian example. The author also fears the consequences of splitting refugees and distributing them among all member states of the Union and concludes his entire article with the following statement: "The flood of immigrants will continue. Associations with the influx of foreign peoples to Rome are obvious" (Semka 2015).

A discussion was sparked in the course of speculations as to the fate of refugees landing on the shores of Europe about whether the flood of immigrants would also swipe through Poland. The Fakt daily informed about Poland needing to host 3,600 immigrants, which was what the European Committee supposedly wanted when presenting the proposal of distributing the African refugees among the European Union countries ("Imigranci zaleją Polskę?" 2015). Politician Marek Jurek, an MP at the European Parliament, said in an interview that according to him, Poland should consider welcoming some of the Christian refugees, whereas countries that consider themselves 'multicultural' should welcome Muslim immigrants (Bątkiewicz-Brożek 2015). It is important to note in these comments how diversely, frequently differently, and inconsistently the geographical location of the issue of refugees was presented. On the one hand, we heard about African refugees who were African Muslims, reluctant to assimilate in mainly Christian Europe, including (implicitly) Poland. This is why opponents of 'others' and 'alien peoples' in Poland were of the opinion that descendants of Poles from the East should be invited to our country or, if worst comes to worst, so should be Syrian Christians who, especially according to nationalist circles, are culturally more similar to the citizens of Poland ("Ściaggnijmy naszych" 2015).

Evoking that 'refugee time' in Poland, it is difficult to resist the impression that the spiral of fear against immigrants from Africa was inspired by media. Dr Piotr Wawrzyk warned us that welcoming migrants in Poland would have serious social and economic consequences: as a result of accepting refugees the Polish society will be under threat of serious social tensions caused by economic circumstances, among others. Without work in Poland, refugees would put a serious strain on the Polish system of social benefits and, consequently, on the ailing budget of the entire country (Harczuk 2015). "Defend yourself," was a proposal by Lech Makowiecki who also used very strong language in the following 
warning: "Our government's approval to accept refugees from Northern Africa is a prologue to more trouble; we will soon watch throats being cut not just on television" (Makowiecki 2015).

The voice of father Andrzej Darguła on the pages of Przewodnik Katolicki [Catholic Guide] seemed to be an exception to the rule. He reminded us that Jesus was a refugee whom his disciples welcomed, and the world obligates Poles who call themselves Christians to accept refugees also because Polish citizens, who for tens of years have been migrating from their country, keep being welcome in other countries of the world (Darguła 2015). Regional dailies also published a translation of an article by Tom Kington about the journey "from the hell of Africa to the land of dreams" (Kington 2015). Kington described the fate of Eritreans who fled their country that was the first on the list of states that censor media and prohibit the freedom of speech. He showed how dangerous the journey through the desert and the Mediterranean was and what they went through to reach the dreamed-of land of peace and serenity.

Most media publications analysed for the purpose of this monitoring indicated that acceptance of immigrants should not be Poland's problem. As a country and fatherland, it should look to welcoming its citizens who live beyond its eastern borders or, if there is no other choice, to support Christians who are culturally close to Poles. The following is an opinion that supports this claim: "[acceptance - ed.] of alien cultures is most of all not a financial problem. Poland has not had and still does not have any economic interest in Northern Africa. Profits from these countries have enriched the Italian, French, and British people and hence it is their problem. We have our duty to Poles who live in the East (the lands of the First and Second Republic) and to persecuted Christians, wherever they are. I say it as a Catholic woman who is ready to give her tax money for this purpose" (Arciszewska-Mielewczyk 2015). On the other hand, Jan Rokita described the situation of the refugee climax in Europe as the "flood of African and Asian hordes." He also claims that "the Europeans no longer want refugees because they don't want the European democracy to become the democracy of Asians, Arabs, and Negroes." He also added that "this probably sounds bad from the perspective of political correctness, but without understanding this basic fact it is impossible to seriously discuss the issue of refugees" (Rokita 2015).

Paweł Kukiz was even more blunt in his comments: "Probably, immigrants from Africa are supposed to divide and weaken the Polish nation. Our society - dignified, wise, and independent - was never really in favour of the powerful of this world. Perhaps we are to leave our lands that would then be used for the purpose of settling the people who are easy to control and manipulate" ("Z ostatniej strony" 2015). 
Szymon Hołownia's appeal interfered with the media statements that were loath of refugees. The journalist stated explicitly that he is ashamed of some Poles. He explained: "We like to think and speak of ourselves as a nation that has been sorely tested throughout its history, but still very noble; somehow singled out by God. And here is this God standing at our door, and some of us dare say: sorry, but no thanks; be off. For now we are poor, but when we become prosperous we will welcome you. You are surely bringing your strange culture here, you'll start molesting our women and blow up our editorial offices." This is how Hołownia ends his statement: "Poles are facing trying times: our mouths have for years been full of stories of our Christian values, love of freedom, and us being the Messiah of nations. [...] What can you do? Two things. First of all, help those who work in Africa, Syria, in Asia and try to improve the lives of people right there so they do not have to make this dramatic decision of emigrating to Europe. Secondly, when they do arrive with their families at our door, do not shut the door in their faces" (Hołownia 2015).

Prof. Paweł Boski encouraged us to get to know individuals of African descent who have already settled in Poland and motivated the media to show the question of refugees using examples of individuals: "It is worth to include in the debates those people who are not ethnic Poles. It is time to get away with talking heads who don't know what they are talking about. We have individuals in Poland who do well; two parliamentarians or doctors who have been working in Poland for years are but a few examples. There is a need to convince ordinary Poles that a refugee or an immigrant is often an interesting, cool person, specialist, and a neighbour" (Dereszyński 2015).

However, analysed media texts are dominated by reports that associate refugees with the phenomenon of militant Islamism and threat of terrorism. This, by the way, is supposed to show that failure of the "multi-culti" idea or, as some individuals want to call it, ideology. Opponents of this phenomenon explain that multiculturalism failed in practice, even in the open Western Europe: "it did not work out anywhere, and everywhere in the West the politics of multiculturalism failed utterly. Native inhabitants of what is now immigrant quarters begin to move out, because they do not feel safe among their new neighbours coming from diverse cultural backgrounds" (Graczyk 2015).

Super Express daily was especially active in scaring Poles with African and Middle Eastern refugees during the initial months of the migration crisis. The following discourse was used to address its readers: "There is work and apartments for them, but not for us" - the tabloid quoted some Poles as saying. With a high degree of certainty it stated that refugees will be guaranteed shelter, food, and free medical care. It also fuelled the negative public sentiment with the following words: "This situation may potentially give rise to resentments 
among Poles" - we read in this daily ("Dla nich są praca i mieszkania, a dla nas nie ma" 2015).

Majority of texts devoted to refugees from Africa or, as time passed, also from the Middle East and Syria, are dominated with such words as "flood," "barbarians," or "human tsunami," in order to stir the phenomenon of dehumanizing foreigners. Should one attempt to simplify media messages, especially the negative ones, the image that would emerge from these texts would be that of inhuman creatures trying to overtake the European continent by using its own weakness. This very weakness of the Europeans and - consequently - the advantage of non-European refugees is based on natural and moral "dominance": in one of his texts, Tomasz Terlikowski states that decadent Europeans do not have this vitality of peoples who are migrating from Africa and the Middle East that according to him are civilisationally inferior, but often morally superior to Europe (Terlikowski 2015).

References to the fall of the Roman Empire also appeal to readers' and viewers' imagination. In the opinion of the opponents of pro-immigrant politics of Europe or Poland, the wave of refugees will inevitably lead to the death of Europe, as the refugees are supported by the so-called Islamic State that intends to conquer the European continent. This fear and the atmosphere of insecurity increase proportionately to the information from Paris or the state of emergency in Belgium. These events shift the centre of gravity towards Islam. From this point on, media more frequently point at Africa and even more so at the Middle East.

According to texts that exist in the public domain, refugees are also not just potential terrorists, but according to Jarosław Kaczyński, president of Prawo i Sprawiedliwość [Law and Justice] party, also carriers of dangerous diseases. In one of his public rallies, Kaczyński warned: “These are issues associated with all sorts of threats in this sphere. We can already see cases of very dangerous diseases that have not been seen in Europe for a long time: cholera on the islands of Greece, dysentery in Vienna, all sorts of parasites and microbes that are not dangerous for those people, but dangerous here. It does not mean that we must discriminate someone... But it is important to check" ("Kaczyński zastanawia się, czy uchodźcy sprowadzą do Polski choroby" 2015).

According to the member of the European Parliament, Mr. Ryszard Czarnecki, Germany is responsible for this situation and the refugee crisis in Europe. Paraphrasing Czarnecki's words: since the world received the message and the image of a warm welcome, then a person from Zanzibar "no matter if he is an Arab or a Negro," will decide to come to this Europe, but he may be disappointed, however, that within the frame of a European accord he may end up not in Berlin but in the neighbouring Poland. This way he suggests that the main wave of refugees is coming from Africa and that even liberals, who will not say 
it during open debates in the European Parliament, are not thrilled with immigrants and refugees. He also blames political correctness for everything. In order to fend off this adverse phenomenon, Czarnecki illustrates his text with an image that brings about mainly racist associations: it portrays a figure dressed in Bavarian attire and other German attributes that evoke an offensive vaudeville and iconography from the American South of the time of racist segregation (Czarnecki 2015).

A female candidate of Platforma Obywatelska [Civic Platform, PO] also used negative associations with refugees during the Polish election campaign season. Printed materials whose aim was to promote Katarzyna Anna Bielańska (number 21 on the Krakow list of $\mathrm{PO}$ ) included a photographic collage that presented the image of Bielańska accompanied by a black burger and economic refugees. From the illustration we find out that the burger is black and Bielańska says "YES" to it, whereas refugees are economic and she says "NO" to them - such were the inscriptions under the images Bielańska used in her campaign. The appearance of such a flyer in public domain became one of media themes that activated other members of the PO party to act, to criticise their colleague, and to renounce the launched communication that included burgers and refugees. At some point, explained after being accused of racist implications, Bielańska herself began to explain that "The black colour of the bun refers precisely to the skin colour of the refugees that is darker than the skin colour of Polish people. This is why this rather than another product is used here. There is no racist undertone here, because I am not a racist myself." Apparently this is not the first such controversial leaflet by Bielańska. Her previous slogan was: "Your alderwoman. Satisfaction guaranteed" ("Kandydatka PO promuje się czarnymi burgerami i łączy je z uchodźcami" 2015).

In summary, readers and viewers of the media coverage of refugees, analysed in this report, received mixed messages. Super Express is the best example: first it alarms us about 90,000 Arabs flooding Poland and then it joins in on the action titled "Refugees in Europe" whose purpose is to dispel myths about immigrants. Only few media outlets avoided the trap of threatening people with refugees and consequently accustomed its readers to the problem of the immigration crisis in the European Union. Newsweek, Przeglad, and Gazeta Wyborcza, are those very media, with Gazeta Wyborcza taking a clear lead.

\section{Politicians, sportsmen, and 'saints'}

In the Fall of 2015, the composition of the Polish Parliament changed quite significantly, which fact caused the most widely recognised politician of African 
descent, Mr. John Godson, not return to the Wiejska Street. He owed his fame mainly to the fact that he was the first African person who managed to build his career from the self-government level of Łódź all the way to the Polish Parliament in Warsaw. Godson was also able to make his media presence known and was also active on social network sites where he used his self-presentation abilities and public appearances as pastor. Initially, he distanced himself from Africa and Africans, emphasising that Polish people chose him to represent them as an MP and clearly distinguished his African identity from exercising his parliamentary mandate.

Information that appeared in public domain in 2015 about him referred mainly to the end of John Godson's political career. Godson then changed his party membership (from Polska Razem [Poland Together] to Polskie Stonnictwo Ludowe [Polish People's Party]), but the political switch did not help him extend his parliamentary life. In an article devoted to him in the Gazeta Wyborcza daily after he had already failed to secure his MP bid, Wioletta Gnacikowska and Piotr Wesołowski wrote about Godson's new mission and just before he ended his term if office Dziennik Łódzki daily reported on conflicts and lack of activity from the Łódź Parliamentary Team led by Godson himself. According to the Łódź-based media, the reason was Godson's involvement in a campaign preceding elections to the European Parliament and in the campaign for the President of Łódź (Darda 2015).

The journalistic summary of the political legacy of the former MP included recollections of his beginnings in Polish politics. We read about him wanting to join Prawo i Sprawiedliwość [Law and Justice], but party authorities did not respond to his application, so he joined Platforma Obywatelska [Civic Platform], first taking the mandate after Hanna Zdanowska and then winning the elections. "Godson liked to argue with known people. He criticized Kuba Wojewódzki for his almost racial statements" ("Ostry protest Godsona ws. Wojewódzkiego" 2011). He opposed legalizing civil unions by saying: "My views were shaped by the fact that I am a Christian, I have been a pastor for many years, and by the Holy Bible. I think homosexuality is a sin, because this is what the Bible says." He also opposed "introducing party discipline in voting on worldview matters" (Orliński 2012) and this is why in 2013 he left Platforma Obywatelska together with Jarosław Gowin and Jacek Żalek and established the Polska Razem party. Leaving Donald Tusk's party proved to be John Godson's political suicide. From that point on, he experienced more failures associated with his conservative views as a politician, but also as a result of his inconsistencies in voting in the Polish Parliament (as an MP from Polska Razem, Godson voted in favour of the vote of confidence for Donald Tusk's government). He did not make it to the European Parliament. He lost his bid for the President of the city of Łódź. 
His association with the Polskie Stronnictwo Ludowe also did not help, after it did well in self-governmental elections. He will be remembered for a famous statement that he made when appealing to the Polish people to not be afraid of having more children. After the fall elections, he decided to rest and move on to missionary and humanitarian activity and to combine it with business. As Godson claims: "Business and politics are just tools. Service and following one's calling is the crucial thing." Godson did not return to politics - as he declared in 2015 in the Gazeta Wyborcza daily (Gnacikowska and Wesołowski 2015).

In other interviews he also revealed the same attitude. For instance, asked by the Super Express daily about whether he would be interested in joining the new ruling majority associated with Prawo i Sprawiedliwość, he responded that he dissociated himself from politics. At the same time, he emphasised that he has his hands full, because he is running three foundations in Poland, one in Nigeria, and manages companies that mediate contacts between the Polish business and Africa ("Jestem misjonarzem, delektuję się wolnością" 2015).

However, the second African MP is a member of the Polish Parliament - Killion Munyama from Platforma Obywatelska representing the Wielkopolska [Greater Poland] province, although we hear much less about him because he seems not to be seeking publicity. As opposed to Godson, he did not comment on worldview issues frequently discussed in the Parliament.

Killion Munyama comes from Zambia and he became known to the Polish community as an academic in Poznań, but also as a man with a healthy distance from himself: "Known from politically incorrect sense of humour he is known to have said to another black parliamentarian, John Godson, during a closed session of Platforma Obywatelska: "John, when it comes to civil unions we are way behind them Niggers" ("Wielka lista posłów” 2015).

However, it was not jokingly when Killion Munyama, the MP, referred to changes introduced to the Constitutional Court by Prawo i Sprawiedliwość after its taking over the rule of Poland: "Haste is an inherent feature of the banana republic" ("Pośpiech jest immanentną cechą republiki bananowej" 2015). His open statement during a parliamentary session aroused laughter. Some commentators interpreted the reaction of other MPs as laughing at the MP, an almost racist behaviour. A Dominican, father Paweł Gużyński sharply commented on this behaviour on his Facebook profile: "An MP asks a question and allegedly Catholic Poland is laughing! God is born and I am trembling!" (Gużyński 2015) ${ }^{4}$ Many users of this social medium reacted to father Gużyński's post and tried to explain the laughter and the self-evoking. However, father Gużyński defended his reaction and responded to the comments directly: "It is the fact that they did

\footnotetext{
${ }^{4}$ A post by fr. Paweł Gużyński from Dec. 22, 2015, Facebook.com.
} 
pay attention to the black colour, to the devil, to bananas, speaks volumes about the MPs and their racism. This is precisely what interpersonal racism is about - operating with such associations as a black (person) - devil, a black (person) bananas, etc. We've been like that since Cain and Abel" and added: "Racism is a $\sin ^{\prime \prime}$ (Ibidem).

As opposed to John Godson, Killion Munyama is not visible in media. In the previous term of office it was Godson (and likely only him) who was associated with the 'phenomenon' of an African MP in the Polish Parliament. Awareness of two MPs of African descent in the Polish Parliament was not widespread. It was only the statement about the banana republic that helped Munyama mark his presence in the public media discourse. Unfortunately, this statement was accompanied by hostile and mocking reactions in social media. Opinions about a 'Negro' teaching Polish people by saying that the Poles do not deserve the banana republic was interpreted as "circus-like" that is only possible to occur in the Polish Parliament (Ibidem). Yet, there was no continuation and media did not pick up on Munyama any further.

Aside from politicians, the Polish media traditionally took note of the presence of African athletes. What is extremely important is that they did not just limit themselves to a portal that thematically deals with African football - afrykagola.pl, but they also made their way to high-circulation press titles. Mentions of athletes of African origin present not just footballers, but also representatives of other disciplines. The article about Katrin Kargbo may serve as a good example; this is how she was characterised: "she has Russian and African blood and promotes the town of Niepołomice around the world" (Agaciak 2015). Katrin Kargbo, "the exotic beauty from Ukraine" (Ibidem) is better-and-better known in the Małopolska [Lesser Poland] province but also in all-Poland media. Asked about Kargbo, inhabitants of Niepołomice responded: "She is our chocolate Ukrainian girl, dance and fitness instructor" [...] "What? A Ukrainian? No; she is Polish! She already has our citizenship [...]" (Ibidem). From the article we find out that Kargbo came to Poland on invitation of the Traditional Karate Academy. As a sought for instructor and a good competitor, she had no problems making her name in sports. She is likely not going to return to Ukraine - her father came from Sierra Leone and her mother is a Russian from Eastern Ukraine whom the young athlete plans to bring to Poland. Kargbo herself declares that nowadays she mainly feels as the citizen of Niepołomice. Currently, she is also a dancer, boasts friendship with the footballer Robert Lewandowski's wife and is an extremely busy person - in April of 2015 her calendar was already full until October (Ibidem).

However, the Polish media most frequently mention footballers from Africa who make their way to the Polish League. The information present new players 
or those the Polish fans already know. Jorge Kadu, a player for the Miedź team from the town of Legnica who comes from Cape Verde may be a good example. The article devoted to him was not limited only to Jorge Kadu's sports achievements. It also became a good reason to present the homeland of Kadu who decided to leave his country when he "dreamed of an adventure with European football" (Pęczkowicz 2015). The text presents the player's home town, provides information about the archipelago, and finally addresses the temperature "that rarely falls below 20 degrees centigrade. As the player for Miedź Legnica says, it is the ideal climate for playing football." Kadu speaks positively about his encounters with Poles: "the people are nice and helpful every step of the way - he admits" (Ibidem).

Polish media also provide negative information about aggression against African footballers or teams that have African players. These cases are publicised by journalists who follow the stories of Africans in the Polish League. As Michat Zichlarz, one of the greatest experts on the African football in the Polish media bluntly writes "a few dark-skinned players of the four-league LZS Piotrówka were hit right in the face" (Zichlarz 2015). He referred to an incident in Strzelce Opolskie: a 30-people group of pseudo-fans beat up six players, one of whom ended up in hospital. One of the victims of the assault, Eric Tala, said: "I have played football in Zimbabwe and in the United Arab Emirates, but it is the first time I have experienced something like that" (Ibidem).

As Zichlarz reminded us, it was not the first such case in Strzelce Opolskie; beatings had taken place there before as well, just like in nearby Opole. Thanks to exposing this case, television news services mentioned the beating in Strzelce. Tala announced that if the safety level does not improve, he will leave our country (Ibidem).

Father John Bashobora, a priest and a charismatic from Uganda, also enjoyed a relatively high interest of the Polish media. Apparently, he has so far been one of the very few individuals from Africa who attracted thousands of Poles to meetings. "What did Poles love a Ugandan priest for?" Well, Życie na Goraco weekly went on a quest to find the answer to the question of Bashobora's phenomenon. The magazine seems to answer the question right away: "A 65-year-old female participant in the National Stadium retreat was cured after 17 years of ailing" ("Za co Polacy pokochali ugandyjskiego księdza" 2015).

According to Życie na Goraco "[o]rganizers sold approximately 40,000 tickets; as many as for a large-scale rock concert or an important sporting event [...]. Hundreds of thousands of people may have had contact with him." Spectators arrived from the entire country - younger and older alike. The retreat in Warsaw was not the first and not the last visit of the Ugandan in Poland; it was emphasised that none of the retreaters is as popular and is able to fill a stadium 
in Poland. Bashobora's vital powers were also appreciated; after all, "despite being 69 years of age he works tirelessly and only sleeps for a few hours a day" (Ibidem).

The figure of father Bashobora is accompanied by an aura of sainthood. Media recall stories from his life when his aunt attempted to poison him when he was but a child, but the bowl with poison broke. Similarly, a story was also recounted of a car crash in Poland where the clergyman from Uganda was its only survivor. However, what brings thousands of Polish people to meetings with him, is most of all the belief in Bashobora's healing power: "I know of a young woman who is here with us, who touched her left breast during the prayer for healing and found a lump there. When you touch this place now, you won't feel the lump anymore! Let this person raise her hand! Do not be afraid to attest!" - father Bashobora was quoted as saying (Ibidem).

Krzysztof Ziemiec, a National Polish Television, TVP, network anchor contributed to the popularity of Bashobora. In 2014 he interviewed him, for which fact he was widely criticised. However, John Godson also believes in the healing powers of Bashobora. He was to say in one of interviews that he is not surprised with the "extraordinary events. Believing in such things is common in Africa, and people in Europe criticise everything and doubt when they do not understand something" ("Dziś wieczorem - Ksiądz Bashobora: Europa ma zegarki, Afryka ma czas" 2014).

The African who gathered 100,000 Poles in one place in 2015, also has his critics. Father Tadeusz Isakowicz-Zaleski doubts the practices of the Ugandan priest and claims that "there are no Church documents that would confirm that." He also noted that the phenomenon of father Bashobora is widespread only in Poland and so he added that he "did not understand why he chose our country as the location of his activities" (Krzyżak 2015).

\section{In the world of 'our-other' celebrities}

Celebrities of African descent play an extremely important role in creating the image of Africa and its people. They appear in popular shows, are some of the most popular television personalities, and sit in television show jury boxes. At the same time, they begin to share with us their experiences of living in Poland, having the status of being one of 'us,' because of being born and raised in Poland, but also of being 'other' because of being born in a Polish-African wedlock and associated with Africa due to their fathers' descent.

Omenaa Mensah, a well-known weather presenter was most frequently mentioned during the period of the media monitoring this report is based on. As 
a well-recognised individual, Mensah's career in media has already been quite long. Aside from working for television, she runs her own foundation - Omenaa Foundation, and she wrote a book about her experiences, titled Gorzka czekolada [Bitter chocolate].

"Too black in Poland, too white in Africa - nowhere is Omenaa Mensah just right. Her exotic beauty made enemies, but it was a great plus during the casting for a TVN weather reporter" - Onet.pl portal reported, and it was added that "[t]oday, she uses her popularity: she encourages tolerance via her book Gorzka czekolada and her foundation is building a school for street children from Ghana who are taken care of by Polish Salesians. She says 'why not if it would help her finance the construction of the school' to those who would prefer to see her in a nude photo session rather than as a writer" (Sztyler-Turovsky 2015). As she states, the idea for the book came a while ago already, but Mensah's decision to write it was directly influenced by a letter: "I read a letter from a mother of a seven-year-old Sami - half-Polish and half-Surinamese. The girl went to one of Polish schools and there she encountered a wave of intolerance, which bore a huge impact on her. I wrote back to her mother and told her to stay strong and to build the sense of self-worth in her daughter, at any price. Only then such situations will make her daughter strong. When reading the letter I realised that thirty years have already passed and little has changed in Poland, so much needs to still be done" (Ibidem).

Then, allegedly she called her own mother who confirmed to her that when she attended school she kept coming back home in tears for the first two years. As a child of a Polish woman and an African man she stood out by the way she looked. Her name also stood out; she got it on purpose from her parents: "My parents could call me Basia or Kasia, but they didn't. By giving me my name, they emphasised that I am half-African from the Ashante lineage. Since I was a baby they taught me to be proud of my origin" (Ibidem).

The promotion of the book enjoyed high interest especially because its author is indeed a celebrity. The internet bookshop Matras encourages potential readers with the following words of Mensah's: "I most frequently order a latte in Dzien Dobry TVN [Good Morning TVN] café. I like coffee with cream even though there is quite a degree of provocation in it. When I meet people in business, I often notice that people are reluctant to order black coffee in my presence. Maybe they are afraid that I would consider it as an allusion to my skin colour? Omenaa Mensah about the life of a coffee-skinned woman in Poland: sometimes amusingly, sometimes bitterly..." ("Gorzka czekolada" n.d.).

Mensah's purpose is to counteract stereotypes. She thinks it is time to break away from the capsule of imagery Poles have found themselves in. In the aforementioned interview for Onet, she said: "Let's rid ourselves of stereotypes that 
are within us, because those Poles who go abroad are also discriminated against because of their being Polish. We don't want others to think about every Polish person that they are alcoholics or car thieves. It is not true and it is very unfair" (Sztyler-Turovsky 2015). The purpose of Omenaa Foundation is precisely to break stereotypes. On occasion of Gorzka czekolada promotion the TVN presenter indicated her non-governmental organization as a way of getting actively involved. She is therefore an example of a person who does not just diagnose an issue, but comes out with an idea for solving it. Consequently, she is becoming a conscious ambassador of her father's continent of origin. Omenaa Mensah's father, too, debunks another myth about Africans. He is an accomplished heart surgeon who works in a hospital in London.

Mensah also pays a lot of attention to hate speech and is a clear voice against hate wave: "A few years ago I met a woman who had worked in Western press for five years. We talked about online hate. She told me that while working abroad she had never encountered as much venom as in texts coming out of Poland. I have a distance towards my exoticism. I allow myself to joke about my colourful looks, but I do not give my consent to anyone to call me black trash, prostitute, or bamboo, with impunity" (Ibidem). Basing on this statement, we can note a significant turn in the question of the perception of African origin individuals: when we compare Mensah's latest statement with what she spoke about in 2008 in the Gala weekly, the differences are significant: "Plus, I have quite a distance to myself and the colour of my skin. As a girl, I often heard spiteful comments and ridicule behind my back: Murzynek Bambo, czarnuch [Nigger], and this is why I am so totally indifferent to it" ("OMENAA MENSAH: Kolorowa dziewczyna" 2008).

Most importantly, Omenaa Mensah frequents women's and lifestyle magazines of all-Poland range. 2015 was also a special period due to the publication of Gorzka czekolada and her foundation's activities. Concurrently, Mensah reveals to media consumers her own discoveries of Africa, because she only recently visited her father's continent for the first time, as an adult. She shares with us her observations and tries to promote Africa not just as a place that is characterised by the urgent need for assistance, but also as a place that is full of chances and perspectives of developing business activities. There are three dimensions to Mensah's narration: the first one is she herself and the life of a woman with a different skin colour in Poland, combined with the story of a successful individual. The second is her striving to familiarise the Poles with Africa and to counteract stereotypes. Finally, the third - Ghana and building a school for poor children.

Omenaa Mensah is presented in media as an attractive and successful woman. However, at the same time, her image is strengthened by the fact that she did not fear any work and - as she confessed in an interview - she earned her 
first money making braids. She is presented as a "volcano of energy" with her calendar so full that "it would make a few people very busy: "She runs training sessions, works for television, builds a school in Ghana, designs furniture. She cannot do only two things: sit still and not help" (Kumanowska 2015; Sadowska 2015).

Omenaa Mensah has a bi-national identity: on the one hand she feels Polish and on the other - Ghanaian. She feels at home in both countries. She rests during her vacation in Ghana, because there she can also help children. She then speaks of "distancing" herself from life (Rawicz 2015). Mensah also encounters criticism from the Do Rzeczy weekly. According to Kamila Baranowska, the presenter "struggles for people's favours and to sell her book. This is why she is telling all sorts of things. That she is discriminated against sometimes as well." Baranowska describes Mensah as "the same woman who taught self-respect by means of participating in an erotic show" ("Obserwator - Kamila Baranowska Na próżno" 2015).

Responding to these media accusations, Mensah explained that she is happy to be stirring emotions. She admits without hesitation that participation in an erotic show, titled Red Light was a spring board for her career. She is not ashamed of her past, but reminds us that she has been hearing racist comments since childhood. In her interview for Gala she referred to "the wave of hate" that she encountered when her book came out and included some statements that regarded racism. On the one hand, she speaks of distance she has for her being different, adorning it with anecdotes, and on the other hand she confirms that she found it very hard to participate in the Polish reality, because of being a Murzynka [A Negro Woman]: "People don't realise how many times I heard about 'asphalt needing to be lying on the ground, where it belongs,' or that 'I should climb a bamboo tree and stuff myself with bananas'" (Gajda 2015).

In the same interview, Mensah shows herself as a strong woman and refers to the meaning of her name, Omenaa, that she repeated in other interviews as well. She is proud to belong to both cultures - African and Polish. She also describes her childhood and the fact that in the 1980s nobody treated things such as racial discrimination seriously. But she also remembers students who found it quite disrupting to be attending classes together with a Murzynka.

Omenaa Mensah translates her recognition and contacts into concrete support of other celebrities as well. Actions with other known people are to aid her in raising funds for building the school in Ghana. Special calendar and special dresses were created for this purpose, and Małgorzata Rozenek joined a group of Polish female celebrities involved in Omenaa's foundation's project. "Africa showed me what the real life looks like and how little is needed to really live it" - this is what Mensah said in one of publications on her (Liebert n.d.). 
Omenaa's book and foundation have become reasons for many mentions in media. Mensah visited almost all gossip websites and colour press devoted to the lives of celebrities: Twoje Imperium weekly, Życie na goraco weekly, Flesz weekly, and also Viva! weekly which published an interview with Omenaa and her mother Izabela Mensah. Mensah did a perfect job of using her popularity while emphasising that she has legitimacy to address the issue of Polish racism. Although in her opinion not every Pole but only a few are racist and, as she claims, most of them are men. At the same time, she emphasises that Polish media overlooked the chance to educate the Polish society in this respect and this is why in Poland we still consider Africans as people who wear straw skirts (Maya 2015).

The hate wave as a topic keeps recurring in Mensah's interviews, including those she gives in her home television network - TVN, including the Kuba Wojewódzki show, is especially visible online not just in anonymous comments. Gossip websites such as pudelek.pl called her "Omenaa the 'Red Light Mensah.'” A wave of negative comments described also Omenaa Mensah's book Gorzka czekolada which was considered one of the worst Christmas presents: "Fashion for books written by celebrities is faring very well especially before the holiday season. When potboiler jobs end and so do ideas for interviews, stars of morning shows get to writing down their experiences. And more often they hire someone to do it for them. Thanks to the fact that they do not read anything they are less critical of their own works" ("Pudelek poleca: Najgorsze prezenty pod choinkę" 2015).

Most posts and articles about her suggested that Mensah speaks about racism and her own life story in a calculating way, in order to win media presence. Internet users did not appreciate it when she confessed: "My parents were standing on a bus stop, waiting for a cab, and the cab driver did not let them in, because my father was a Negro. Some people were driving behind my father's car, shouting: Hey, Nigger, give me back my car. They also insulted my mother: you white sl...t, because she was with a black man" ("Omenaa: Wyzywali moją matkę..." 2015).

The commentators did not refrain then from accusing Mensah of trying to arouse sympathy and increase audience ratings with these alleged recollections.

Patricia Kazadi is another celebrity from a Polish-African family. Along with the announcements of her appearing as part of the jury in You can dance, gossip media and celebrity magazines devoted a lot of space to Kazadi. Kazadi's view on the issue of racism in Poland is different than what Mensah claims. She thinks that no such phenomenon exists in Poland, and aggressive behaviour toward individuals of a different skin colour result more from "lack of manners, the need to attract attention, and fear." Kazadi downplays this phenomenon and speaks quite warmly about those who - like her friend's grandmother - declare: "Pati, I am a racist, but I like you" (Gajda 2016). 
Kazadi regrets that the African culture was not part of her upbringing: she was born in Poland, she speaks Polish, and loves pierogis, as she confesses in tabloid. Importantly, though, she is now beginning to discover her father's homeland - the Democratic Republic of the Congo, which she visited only recently for the first time. During this visit, she had an opportunity to perform on stage, together with the greatest stars of Congolese music.

Next report entitled "Kongo story" begins in a rather peculiar way: "When I feel the Congolese soil with my feet, I cry." The interview, accompanied by photos from a special Congolese session inscribes itself in Kazadi's discovery of her Congolese or African identity, which is similar to Mensah's also discovering her father's home. Kazadi claims that she would not be able to live in the Congo, but she would want to visit the country once a year. During her stay in the Congo, she visited a few orphanages and realized high tourist potential of this country (Pytlakowska 2015).

The next, much less known person from the Tri-Town area presents herself in a completely different way. Tonia Ugwu, a model and one of the faces of the All About Freedom festival. Ugwu is becoming recognisable only now, but she confesses that she does feel reluctance of Poles with regards to immigrants, which she thinks results from the fear of refugees that in turn results from the lack of knowledge. Therefore Ugwu herself takes initiative in her own hands. She decided to react when her friends published unfavourable posts about immigrants on social media. She fought the Polish hate wave that she thought the Polish society was really able to stop: "After all, many of those individuals who post aggressive comments online then go for their favourite kabob to a Turkish place or for a spinach cake at Hani's in the Żabianka district of Gdansk. They talk to them, joke together - because they know them, because they consider them one of their own. I am therefore convinced that this hostile attitude can be reversed" (Kozłowska 2015).

When asked about her childhood experiences, Ugwu remembers frequently encountering shouts to the tune of "O, look, a Nigger is coming!" but with time Poles began to travel the world more and developed their intercultural competencies. Yet, this situation was not eternal: "Unfortunately, nowadays it looks like our society, or rather its part, took a serious step backwards. Media, the Internet, and politicians who threaten us with diseases influence this" (Ibidem). This is why Ugwu got involved with the All About Freedom festival; to fend off resentment toward others. She herself comes from a Polish-Nigerian family and her father is one of the better-known inhabitants of the Tri-Town where he directs the Baltic Sea Cultural Centre; Tonia Ugwu wants to show that although she does not have Slavic facial features, she is Polish, like Mensah or Kazadi (Ibidem). 


\section{Conclusions}

What has changed in the perception of Africa and its inhabitants after the five years since the previous media monitoring report? It is hard to resist the impression that Africa is still viewed as this poor, underdeveloped and dangerous continent. And the way it is presented translates into the way individuals of African descent are perceived.

Most frequently, the media search for sensation, human tragedy, and spectacular failures in their portrayal of the world. Positive information has less clout with thousands of reports and wires that reach the Polish press agencies. This is especially so in the case of Africa, located far away from Poland.

In this situation, the very few Africans or individuals of Polish and African descent living in Poland still play the key role in acquainting Poles with Africa and its people. This monitoring has shown that Omenaa Mensah has now taken a lead in this group of people by combining the role of a celebrity and running her own foundation that collects funds for building a school for street children in Ghana. Former MP, John Godson is also involved in charity activities and supports developing business relations between Poland and African countries. Aside from their involvement in charity projects, these individuals reach a wide range of Polish people thanks to their presence in the Polish media, interviews they give, and finally with bold statements they make. It is important that they are in Poland, and are a source of interest due to the roles they play or jobs they do.

It is therefore very likely that showing these individuals, our own foreigners who live in Poland and share their everyday lives with the Polish people that is the best way to integrate and counteract hate speech. They are of 'our' kind even though they look differently and have a different skin colour, but they live among us. They are our neighbours, who also make their living and their lives in Poland, who are high-level specialists, but also often work as blue-collar workers.

There are also other opportunities to talk about Africa. It could be the $1050^{\text {th }}$ anniversary of the Baptism of Poland. Already in very initial years of Poland's existence, during the times of Bolesław I the Brave - son of Mieszko I - a frequently overlooked detail can be noted. During the Congress of Gniezno, Bolesław received the spear of Saint Maurice from Otto III the German. St. Maurice himself came from a Theban Legion of Africa and to this day he is presented in Christian iconography as a dark-skinned individual from sub-Saharan Africa ("Święty Maurycy i Towarzysze" 2016).

The of Poles who became successful in Africa are also very interesting case. The story of Marek Zmysłowski could be a good example. He established an online hotel booking service in Nigeria, called Jovago.com. IT News Africa included Zmysłowski as one of top ten technology-related individuals in Africa. 
He uses a \#Markchinedy hashtag on Twitter, which in the igbo language means "God is leading." Importantly, Nigeria reminds him of his homeland after political transformation; although he does not sweep problems under the rug, he still indicates that "what in Poland is whimsical, such as having a driver, a cook, or a cleaning lady, is an attribute of the middle class in Nigeria" (Karbowiak 2015).

The word Murzyn [Negro] is still doing quite well in the Polish media. It is used as an example of "a dictate of political correctness" (Cieślik 2015), so strongly opposed especially by right-wing media. In their opinion, this very correctness is one of the symptoms of the fall of the European culture. It is also political correctness which paved the way for refugees who in the initial phases of the migration crisis reached the borders of the European Union from the northern shores of Africa. This crisis, just like the narration used to describe it by many Polish media outlets, has led to the creation of an image of 'barbarians' who storm the borders of European Union member states today, just like they did with the borders of the Roman Empire. The atmosphere of fear and the threat of invasion is not conducive to creating the attitude of openness towards individuals from other continents, including Africans. It is also one of the greatest challenges for the integration of African citizens in Poland. Refugees and media reports about them 'flooding' Europe became a pretext for the wave of hatred observed especially vividly in Internet users' comments and in social media.

What is also alarming is the fact that the portrayal of Africa and its positive image is pushed to the margins of the Polish media. This way of portraying this continent and its inhabitants took place in the case of an interview with Alaine Mabanckou, a Congolese writer who visited Poland again. The Gazeta Wyborcza daily published an extensive interview with the writer, where by not skipping his discussion of difficult issues the author bears witness to a different, diverse Africa; an Africa that is being awarded prestigious literary prizes. He also appeals to not be afraid of Africa and "let the continent 'tell us its stories"' (Piekarska 2015).

The Polish media still do not give Africa that very chance of telling its stories. The journalists frequently do not know much about Africa, but get the news handed to them by editorial offices. They could also write about Africa with the assistance of Poles who visited Africa. Ultimately, though, the reports should be written by journalists who have the knowledge which they had gained by multiple visits to the continent. It seems that the only solution and a way out of the problem is what has already been postulated, namely opening media to Africans themselves. Those media will also have to deal with the universality of visual reports and excess of information characteristic to social media. It is this very surface-like approach to becoming acquainted with African themes, and lack of interest in reading longer than a few-sentence texts, that will in the nearest future be the greatest challenge. 


\section{Bibliography}

Duński, P. 2015. “Badanie opinii publicznej na temat integracji obywateli państw afrykańskich w Polsce. The Public Opinion Research Results on the Integration of Citizens of African Countries in Poland." 11 July 2017. <http://afryka.org/download/ raport2015/raportpl.pdf >.

Średziński, P. 2011. "Afryka i jej mieszkańcy w polskich mediach. Africa and its Inhabitants in Polish Media." 11 July 2017. <http://afryka.org/batory/raport_batory. pdf>.

Press:

Agaciak, A. 2015. “Egzotyczna piękność z Ukrainy promuje Niepołomice na świecie" [Exotic Beauty from Ukraine Promotes Niepołomice around the World]. Dziennik Polski. Kronika Krakowska 96/2015.

Arciszewska-Mielewczyk, D. 2015. "Rasistowska presja” [Racist Pressure]. Nasz Dziennik $128 / 2015$.

Bątkiewicz-Brożek, J. 2015. “O tym, czy Polsce grozi islamizacja i kto w Europie broni życia, z Markiem Jurkiem, posłem do Parlamentu Europejskiego" [Whether Poland Is under Threat of Islamization and Who in Fact Defends Life in Europe: Interview with Marek Jurek, MP in the European Parliament]. Gość Niedzielny 19/2015.

Borkowicz, J. 2015. “Młodość, miłość i komunizm" [Youth, Love, and Communism]. Fakt. Historia 31/2015.

Cieślik, M. 2015. "Cenzura w imię równości" [Censorship in the Name of Equality]. Wprost 27/2015.

Czarnecki, R. 2015. "Strasburg, Czarny Ląd, wiatry hipokryzji" [Strasbourg, the Black Continent, and the Winds of Hypocrisy]. Gazeta Polska 48/2015.

Darda, M. 2015. "Zespół parlamentarny się nie spotyka, bo posłowie się kłócą" [The Parliamentary Team Is Not Meeting because the MPs Are Quarrelling]. Polska. Dziennik Łódzki 88/2015.

Darguła, A. 2015. “Jezus uchodźca” [Jesus the Refugee]. Przewodnik Katolicki 20/2015.

"Dla nich są praca i mieszkania, a dla nas nie ma" [There Is Work and Accommodation for Them, but Not for Us]. 2015. Super Express 170/2015.

Drabikowska, A. 2015. "Wyrok za rasistowski napad" [Sentence for a Racist Assault]. Gazeta Wyborcza Kielce 66/2015.

Dereszyński, T. 2015. "Prof. Boski: Polacy nie są ksenofobami" [Prof. Boski: Poles Are Not Xenophobes]. Kurier Poranny 139/2015.

Gajda, D. 2015. “Cieszę się, że wzbudzam emocje” [I'm Glad to Be Stirring Emotions]. Gala 9/2015. 2016. "Słowiańska natura" [Slavic Nature]. Gala 5/2016.

Gnacikowska, W., and Wesołowski P. 2015. "Kolejna misja Johna Godsona" [The Next Mission of John Godson]. Gazeta Wyborcza Łódź 260/2015.

Graczyk, R. 2015. "Pobożny muzułmanin patrzy na Francję" [A Devout Muslim Is Eyeing France]. Rzeczpospolita 172/2015.

Harczuk, P. 2015. "Grożą poważne napięcia społeczne" [The Threat of Serious Social Tensions]. Super Express 112/2015.

Hołownia, S. 2015. "Nie zamykać drzwi" [Do Not Close Your Door]. Pani 7/2015.

“Imigranci zaleją Polskę?" [Will Immigrants Flood Poland?]. 2015. Fakt 123/2015. 
Jankowska, M. 2015. “Chciałem zobaczyć Afrykę walczącą z ebolą" [I Wanted to See how Africa Fights against Ebola]. Express Bydgoski 285/2015.

"Jestem misjonarzem, delektuję się wolnością" [I Am a Missionary, I Savor Freedom]. 2015. Super Express 252/2015.

Karbowiak, M. 2015. “Nasz człowiek w Lagos" [Our Man in Lagos]. Gazeta Wyborcza $255 / 2015$.

Kington, T. 2015. "Z piekła Afryki do wymarzonej ziemi" [From the Hell of Africa to the Land of Dreams]. Polska Gazeta Wroctawska 109/2015.

Kozłowska, A. 2015. "Tonia Ugwu: Wszystko o wolności" [Tonia Ugwu: All about Freedom]. Gazeta Wyborcza. Trójmiasto 248/2015.

Krzyżak, T. 2015. “Nieustająca potrzeba cudu” [An Incessant Need for a Miracle]. Rzeczpospolita 164/2015.

Kumanowska, J. 2015. “MOJA PIERWSZA PRACA, pierwsze pieniądze” [MY FIRST JOB, My First Cash. Claudia 7/2015.

“Listy czytelników" [Letters from Readers]. 2015. Super Express 141/2015.

Magierowski, M. 2015. "Dziennik roku zarazy" [A Journal from the Plague Year]. Do Rzeczy 18/2015.

Makowiecki, L. 2015. “Polaku, broń się sam" [Defend Yourself]. wSieci 19/2015.

Maya, O. 2015. "Nie będę siedzieć cicho" [I Will Not Keep Silent]. Show 8/2015.

"Na urlop do Afryki" [To Africa on Vacation]. 2015. Express Ilustrowany 125/2015.

"Nie taki geniusz" [Not So Much of a Genius]. 2015. Tygodnik Siedlecki 39/2015.

“Obserwator - Kamila Baranowska - Na próżno [Kamila Baranowska: The Observer in Vain]. 2015. Do Rzeczy 22/2015.

Pęczkowicz, J. 2015. "Ceni Lewandowskiego i Milika, a marzeniem jest gra w Porto" [He Appreciates Lewandowski and Milik and Dreams of Playing for Porto]. Polska Gazeta Wroctawska 71/2015.

Piekarska, M. 2015. "Wytatuowana na skórze" [Tattooed on the Skin]. Gazeta Wyborcza Wroctaw 135/2015.

Pierzchala, W. 2015. "Rok i dwa miesiące więzienia za pobicie czarnoskórych na tle rasowym" [14 Months for Racist Assault on Blacks]. Polska. Dziennik Łódzki 106/2015.

Pobihuska, F. 2015. "Koalicja rządzi, koalicja radzi, koalicja odwołuje" [Coalition Rules, Coalition Advises, Coalition Dismisses]. Gazeta Lubuska 50/2015.

Pytlakowska, K. 2015. “Kongo Story.” Viva! 19/2015.

Rabij, M. 2015. "Etat dla Australijczyka" [A Job for an Australian]. Newsweek 22/2015.

Rawicz, M. 2015. “Omenaa: W Nowym Jorku dzieje się, ale wolę Europę” [Omenaa: New York Is Bustling, but I Prefer Europe]. Echo Dnia Podkarpackie 210/2015.

Rokita, J. 2015. "Droga donikąd" [A Road to Nowhere]. wSieci 27/2015.

Sadowska, B. 2015. "Zakochałam się w Afryce" [I Fell in Love with Africa]. Dbam o Zdrowie $7 / 2015$.

Semka, P. 2015. “Dlaczego afromigracja przeraża?" [Why is Afromigration Frightening?]. Do Rzeczy 19/2015.

"Ściągnijmy naszych" [Let's Get Our Folks Back Here]. 2015. Idziemy 22/2015.

Terlikowski, T. 2015. “Zalew ‘barbarzyńców'?" [The Flood of 'Barbarians?']. Gazeta Polska 150/2015.

"W piekle eboli" [In the Hell of Ebola]. 2016. Angora 4/2016.

Wawrzyński, P. 2016. "Słownik reakcjonisty" [Reactionary Dictionary]. Do Rzeczy $5 / 2016$. 
"Wielka lista posłów" [The Great List of MPs]. 2015. Gazeta Polska 44/2015.

Wierciński, J. 2015. “Narodowcy będą w Gdańsku protestować przeciw imigrantom" [Nationalists in Gdansk Will Be Protesting against Immigrants]. Polska. Dziennik Battycki 116/2015.

"Wygrałem walkę z ebolą" [I Won the Fight Against Ebola"]. 2015. Świat Wiedzy 9/2015.

"Z ostatniej strony" [From the Last Page]. 2015. Polityka 31/2015.

"Za co Polacy pokochali ugandyjskiego księdza?" [Why Poles Love the Ugandan Priest?]. 2015. Życie na goraco 31/2015.

Zichlarz, M. 2015. "Pięścią w twarz" [A Fist in the Face]. Sport 81/2015.

Internet:

“Gorzka czekolada." n.d. 10 Jan. 2016. <http://www.matras.pl/gorzka-czekolada,p, 227155>.

Gużyński, P. 22 Dec. 2015. "Poseł zadaje pytanie..." [An MP asks a question...]. A Facebook post by fr. Paweł Gużyński. 11 July 2017. <https://www.facebook.com/profile. php?id=100004987421290>.

Liebert, E. n.d. "Małgorzata Rozenek i jej misja... w Afryce!" [Małgorzata Rozenek and Her Mission... in Africa!]. 1 Feb. 2016. <http://polki.pl/zycie_gwiazd_znaniilubiani_artykul,10044980.html>.

“OMENAA MENSAH. Kolorowa dziewczyna" [A Colorful Young Woman]. 17 Oct. 2008. Gala. 10 Jan. 2016. <www.gala.pl/wywiady-i-sylwetki/omenaa-mensah-kolorowa-dusza-1457?strona=1>.

“Omenaa: 'Wyzywali moją matkę: TY BIAŁA DZI*KO! Dlatego, że była z czarnym'” [Omenaa: 'They Insulted My Mother: YOU WHITE SL...T! Because She Was with a Black Man']. n.d. 29 Feb. 2016. <http://www.pudelek.tv/video/Omenaa-Wyzywali-moja-matke-TY-BIALA-DZI*KO-Dlatego-ze-byla-z-czarnym-10034/>.

Orliński, F. 11 July 2012. "Spór o in vitro. Godson grozi wyjściem z Platformy" [A Dispute over In Vitro. Godson Threatens to Leave Platforma]. 12 Feb. 2016. <http:// natemat.pl/22779,spor-o-in-vitro-godson-grozi-wyjsciem-z-platformy>.

"Ostry protest Godsona ws. Wojewódzkiego" [Godson's Vehement Protest against Wojewódzki]. 10 June 2011. 12 Feb. 2016. <http://wiadomosci.onet.pl/kraj/ostry-protest-godsona-ws-wojewodzkiego/sxlke>.

Piekarska, M. 16 Oct. 2015. “Alain Mabanckou, gwiazda literatury afrykańskiej: Pozwól Afryce, żeby ci o sobie poopowiadała" [Alain Mabanckou, a Star of African Literature: Let Africa Tell Its Own Stories to You]. Gazeta Wyborcza. 1 March 2016. <http:// wyborcza.pl/1,75475,19031394,alain-mabanckou-gwiazda-literatury-afrykanskiej-pozwol-afryce.html\#ixzz4368By16Z>.

"Pudelek poleca: Najgorsze prezenty pod choinkę" [Pudelek Recommends: The Worst Christmas Presents"]. 17 Dec. 2015. 10 Jan. 2016. <http://www.pudelek.pl/ artykul/86997/pudelek_poleca_najgorsze_prezenty_pod_choinke_s/foto_1\#s1>.

“Radio Ebola." 17 Dec. 2015. Gazeta Wyborcza. Duży Format. 11 Jul. 2017. <http:// wyborcza.pl/duzyformat/1,127290,19356189,radio-ebola-jak-sierra-leone-walczy-epidemia-fotoreportaz.html>.

"Rasa grubych" [The Fat Race]. 24 Sept. 2013. Polityka. 1 Feb. 2016. <http://www.polityka.pl/tygodnikpolityka/spoleczenstwo/1556291,1,wykluczeni-xxl.read>. 
Sztyler-Turovsky, A. 5 May 2015. “Omenaa Mensah: pozbądźmy się stereotypów” [Omenaa Mensah: Let's Get Rid of Stereotypes]. 10 Jan. 2016. <http://ksiazki.onet.pl/ gorzka-czekolada-omenaa-mensah-wywiad/rw4173>.

"Święty Maurycy i Towarzysze, Internetowa Liturgia Godzin" [Saint Maurice and His Companions, an Online Liturgy of the Hours"]. 31 Aug. 2014. 12 March 2016. <http:// www.brewiarz.pl/czytelnia/swieci/09-22a.php3>.

Żakowski, J. 15 Nov. 2010. “Ja, Murzyn” [I, the Negro]. Gazeta Wyborcza. 1 Feb. 2016. <http://wyborcza.pl/1,76842,8659493,Ja_Murzyn.html>.

TV:

"Dziś wieczorem - Ks. Bashobora: Europa ma zegarki, Afryka ma czas. Wywiad przeprowadzony przez Krzysztofa Ziemca" [This Evening - Fr. Bashobora: Europe Has Watches, Africa Has Time. An Interview by Krzysztof Ziemiec]. 26 Aug. 2014. TVP Info. 29 Feb. 2016. <https://www.youtube.com/watch?v=ChCM55mgJN0>.

"Kaczyński zastanawia się, czy uchodźcy sprowadzą do Polski choroby" [Kaczyński Is Wondering Whether Refugees Will Bring Disease to Poland]. 13 Oct. 2015. TVN 24. 1 Feb. 2016. <http://www.tvn24.pl/wideo/kaczynski-zastanawia-sie-czy-uchodzcy-sprowadza-do-polski-choroby,1470643.html>.

“Kandydatka PO promuje się czarnymi burgerami i łączy je z uchodźcami. 'Nie jestem rasistką'" [A PO Candidate Promotes Herself with Black Hamburgers and Associates Them with Refugees. 'I am not a racist']. 20 Oct. 2015. TVN 24. 1 Feb. 2016. <http:// www.tvn24.pl/krakow,50/kandydatka-po-promuje-sie-czarnymi-burgerami-kolor-skory-uchodzcow,587553.html>.

"Pośpiech jest immanentną cechą republiki bananowej" ["Haste is an Inherent Feature of the Banana Republic]. 22 Dec. 2015. TVN 24. 1 March 2016. <www.tvn24.pl/ wideo/z-anteny/pospiech-jest-immanentna-cecha-republiki-bananowej,1493245. html?playlist_id=19484.9>.

"Rachela Dolezal, kobieta, która oszukała USA" [Rachel Dolezal: A Woman Who Cheated USA]. 16 June 2015. Superstacja. 